\title{
Seismic Risk Perception Assessment of Earthquake Survivors: A Case Study from the 2005 Kashmir Earthquake
}

\author{
Ikramuddin Bahram, Thomas R. Paradise \\ University of Arkansas, Fayetteville, Arkansas, USA \\ Email: igbahram@uark.edu
}

How to cite this paper: Bahram, I. and Paradise, T.R. (2020) Seismic Risk Perception Assessment of Earthquake Survivors: A Case Study from the 2005 Kashmir Earthquake. Open Journal of Earthquake Research, 9, 403-416. https://doi.org/10.4236/ojer.2020.95023

Received: September 6, 2020

Accepted: November 10, 2020

Published: November 13, 2020

Copyright $\odot 2020$ by author(s) and Scientific Research Publishing Inc. This work is licensed under the Creative Commons Attribution International License (CC BY-NC 4.0).

http://creativecommons.org/licenses/by-nc/4.0/ (c) (i) Open Access

\begin{abstract}
Following the catastrophic earthquake of October 2005 in Kashmir, Pakistan, 215 surveys were administered to earthquake survivors in villages within 50 miles $(80 \mathrm{~km})$ of the epicenter near the town of Muzaffarabad. The survey questionnaires were designed to address perceptions of seismic knowledge, event-related behavior, and opinions of local, regional, and national seismic preparedness and mitigation-representing a rare opportunity in seismic risk assessment. Some of the findings were similar to previous research results, while some were counter-intuitive, surprising, and valuable. Overwhelmingly, respondents stated that they ran away after the quake (vs. praying, taking cover, screaming, or doing nothing). Their trust in local and national governments regarding future earthquake preparedness and mitigation was high ( $50 \%)$, contrary to most prior studies. Less than five percent of respondents believed that "no quake would occur again", while nearly $75 \%$ responded that another quake would occur within 5 - 10 years, another opinion contrary to previous research. This research revealed new aspects of risk perception in the predominant Muslim communities of Northern Pakistan regarding recurrence, post-event action, and regional preparedness.
\end{abstract}

\section{Keywords}

2005 Kashmir Earthquake, Risk Perception, Islam, Hazards Studies

\section{Introduction}

A major earthquake of magnitude 7.6 (MR) struck Pakistan-administered Kashmir on 8 October 2005 at approximately 8:50 am [1]. The epicenter was located 12 miles $(20 \mathrm{~km})$ northeast of Muzaffarabad, the administrative capital of Pakistani 
Kashmir, and only 61 miles $(100 \mathrm{~km})$ northeast of Islamabad, Pakistan's capital [2] (Figure 1). The earthquake resulted in ground-shaking intensity (Mercalli Scale) as high as IX to X in densely populated areas such of Balakot and Muzaffarabad [3] - this study's survey sample sites. This quake is considered "the worst natural disaster in Kashmir" over the past 100 years [4]. It caused 86,000 fatalities and damage to some 600,000 buildings, which included 6298 schools and 782 health facilities [5] [6] and left behind an estimated four million people homeless [7]. Damage was extensive and international support was widespread [8] (Figure 2).

\section{Tectonics and Seismicity of Northern Pakistan}

The Himalayan, Karakoram, and Hindu Kush fault nexus represents one of the most seismically active regions in the world [9]. The location of northern Pakis$\tan$ on this syntaxis is characterized by increased seismicity owing to the convergence of the Eurasian and Indian plates, with the latter slipping northwards beneath the former at a rate of $37-48 \mathrm{~mm} /$ year [3]. This region has a history of being affected by shallow earthquakes originating from the northwestern segment of the Karakoram Fault System [10].

It was the first Himalayan earthquake to be accompanied by surface rupture, reactivating the Balakot-Bagh Reverse Fault (BBRF) and, locally, offsetting the Main Boundary Thrust [11]. A field investigation by Yeats et al. [12], Kumahara and Nakata [13] and Kaneda et al. [14] revealed a surface rupture $70 \mathrm{~km}$ long, with up to a seven-meter vertical separation, mostly along the preexisting BBRF [11].

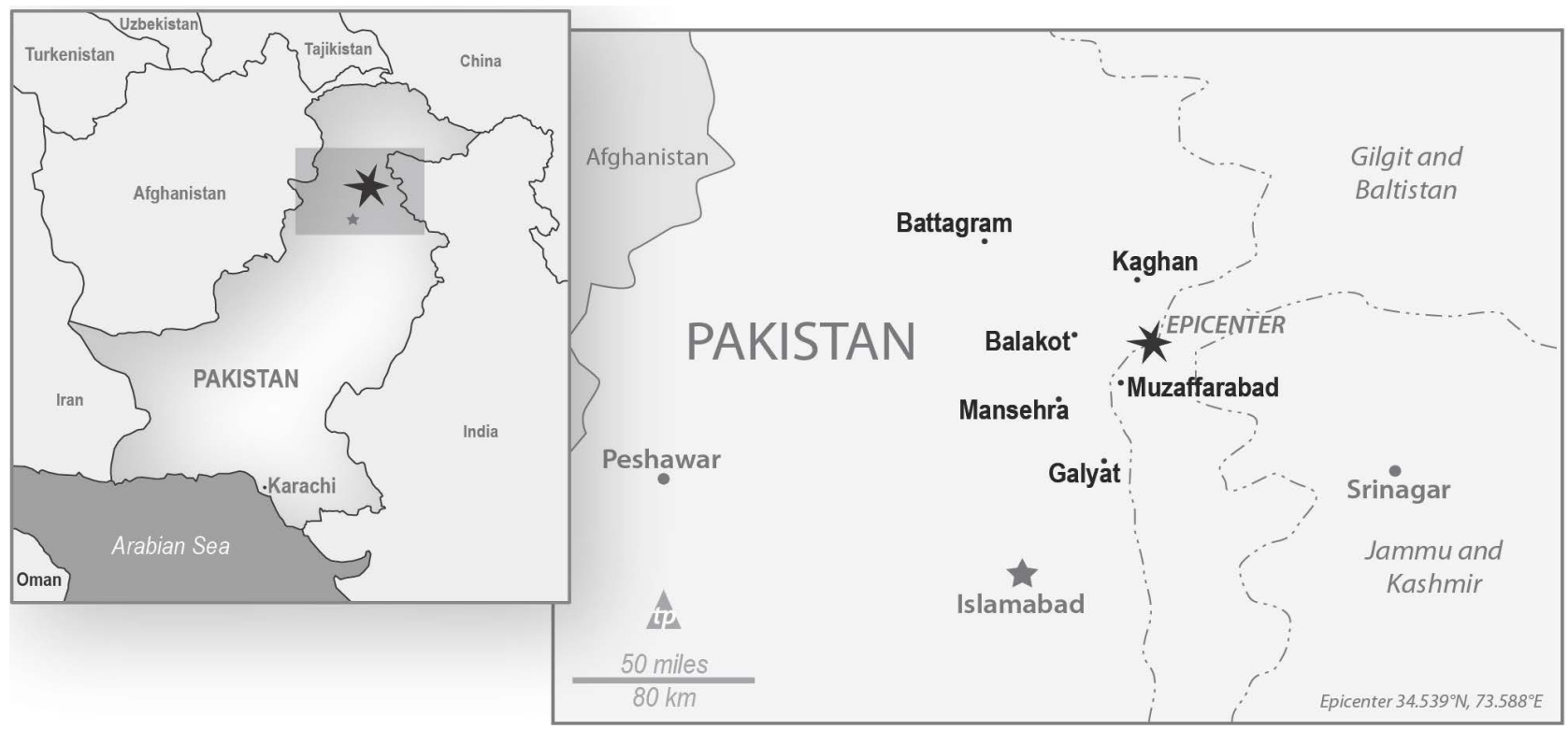

Figure 1. Map (left) of Pakistan with epicenter of the Kashmir Earthquake of October 8, 2005 and study site. The earthquake was felt as far as New Delhi, India while it also caused building collapse in the eastern provinces of Afghanistan. Close-up map (right) of the region most affected by the quake. Highlighted towns represent those where post-event surveys were administered (Cartography by T. Paradise). 


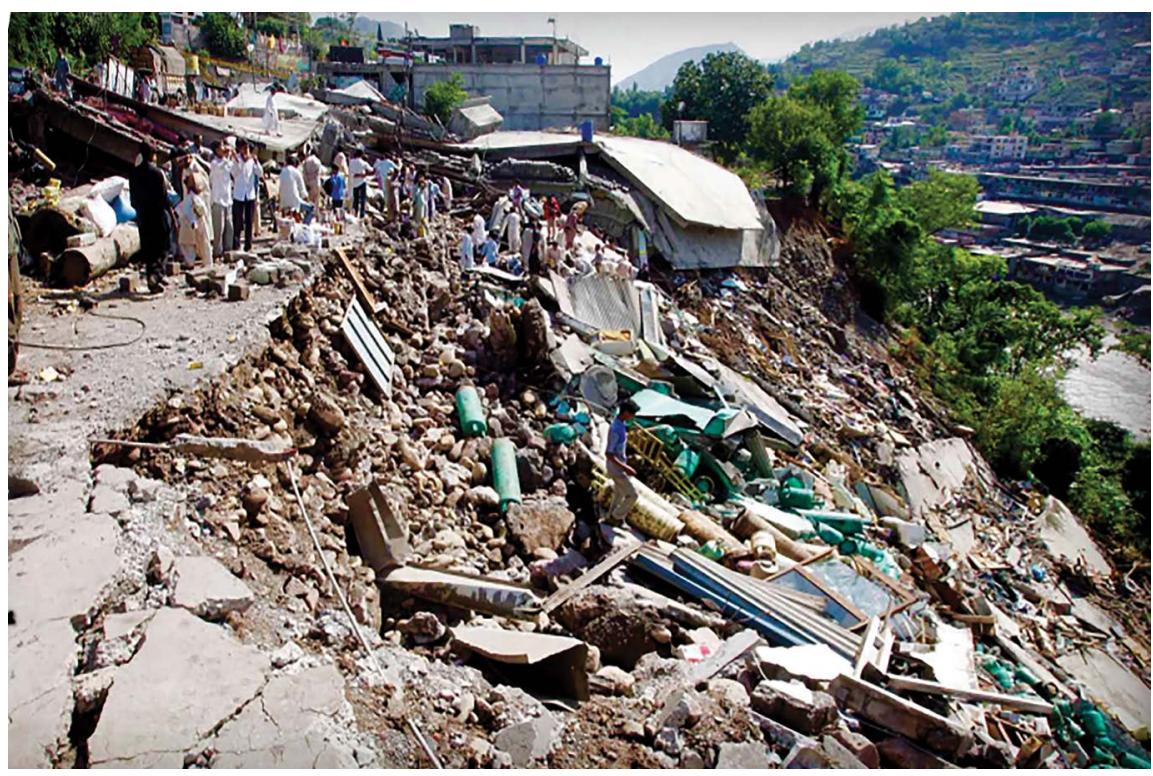

Figure 2. Destruction of structures and hillslopes in Muzaffarabad, near the earthquake epicenter. It was the most devastating earthquake in the history of Pakistan since its birth in 1947 [15].

Across the affected region, mountainsides collapsed causing extensive rockfalls and debris flow that cut-off entire towns, villages, rivers, and roads, leaving many areas inaccessible to aid (Figure 3). The towns of Muzaffarabad and Balakot sustained terrible devastation. Because the earthquake occurred just before the beginning of the region's severe winter, it exacerbated the effects of the tremor while increasing the inability to assist the injured and attend to the dead [16] [17] (Figures 3-6).

\section{Methods and Data Collection}

Besides Kashmir, the most impacted was the northwestern province of Khyber-Pakhtunkhwa (KPK)-formerly the Northwestern Frontier Province-of Pakistan. Three of the most devastated districts in KPK included Mansehra, Battagram, and Abbottabad. These districts witnessed extensive damages and losses of human life. This study was conducted in these communities specifically to understand how perceptions of earthquakes impacted their response or lack of response to the quake.

Since earthquake preparedness and mitigation is related to perceptions of hazard and risk [19], a Likert scale survey instrument was designed to address demographics, earthquake experience, and seismic risk perceptions of the hardest hit three districts of KPK-the study site for this research. Following Haque and Blair [20], Hutton and Haque [21], and Paradise [22], these survey questionnaires were designed to obtain a representative sample of the most impacted three districts of KPK namely Abbottabad, Battagram, and Mansehra at the Union Council (UC) level (village). The survey instrument adopted a conventional Likert-scaled response technique divided into two parts. 


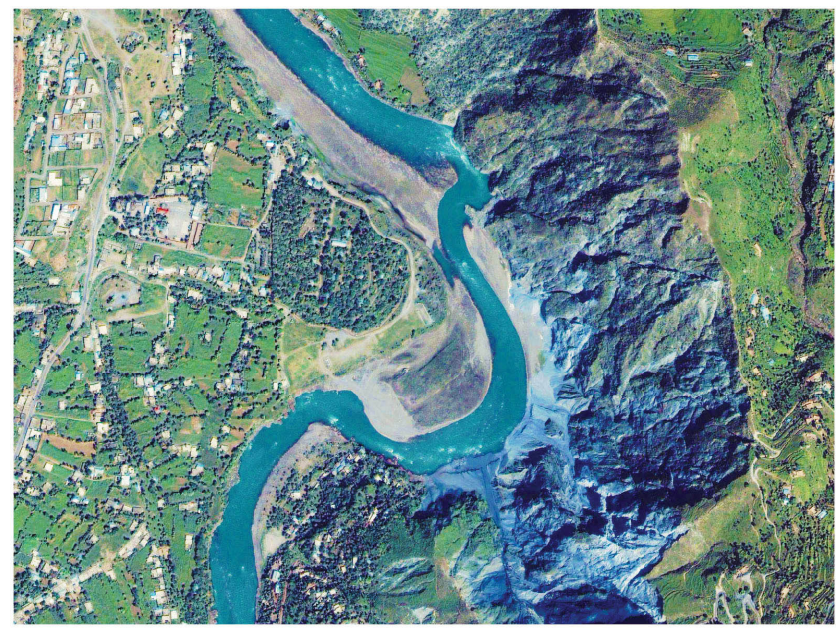

September 15, 2002

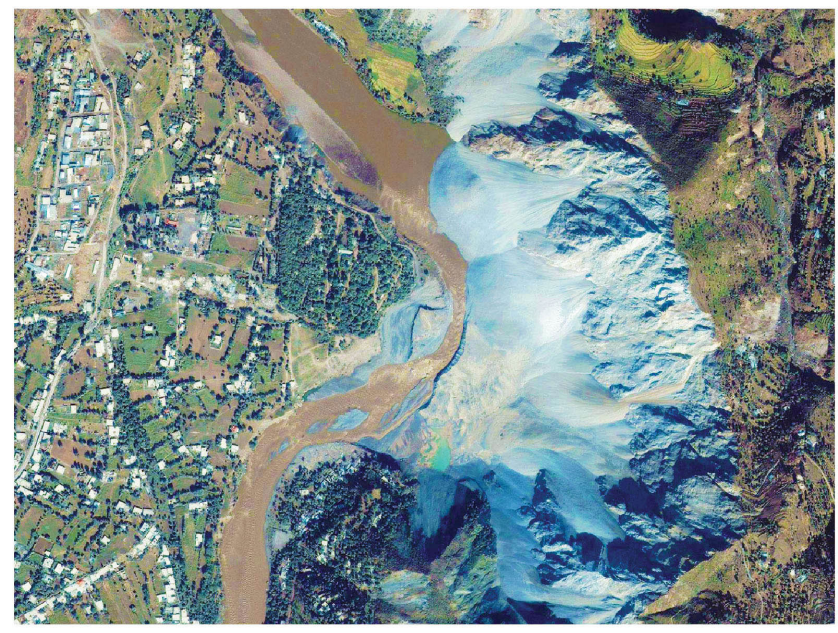

October 9, 2005

Figure 3. Ikonos Satellite image of Makhri, a village on the northern outskirts of Muzaffarabad. Images of Makhri on a Neelum River meander before (left, 2002) and after a landslide inundated the river and bars (right, 2005), following the Kashmir Quake of 8 October 2005 (Imagery from Digital Globe [18]).

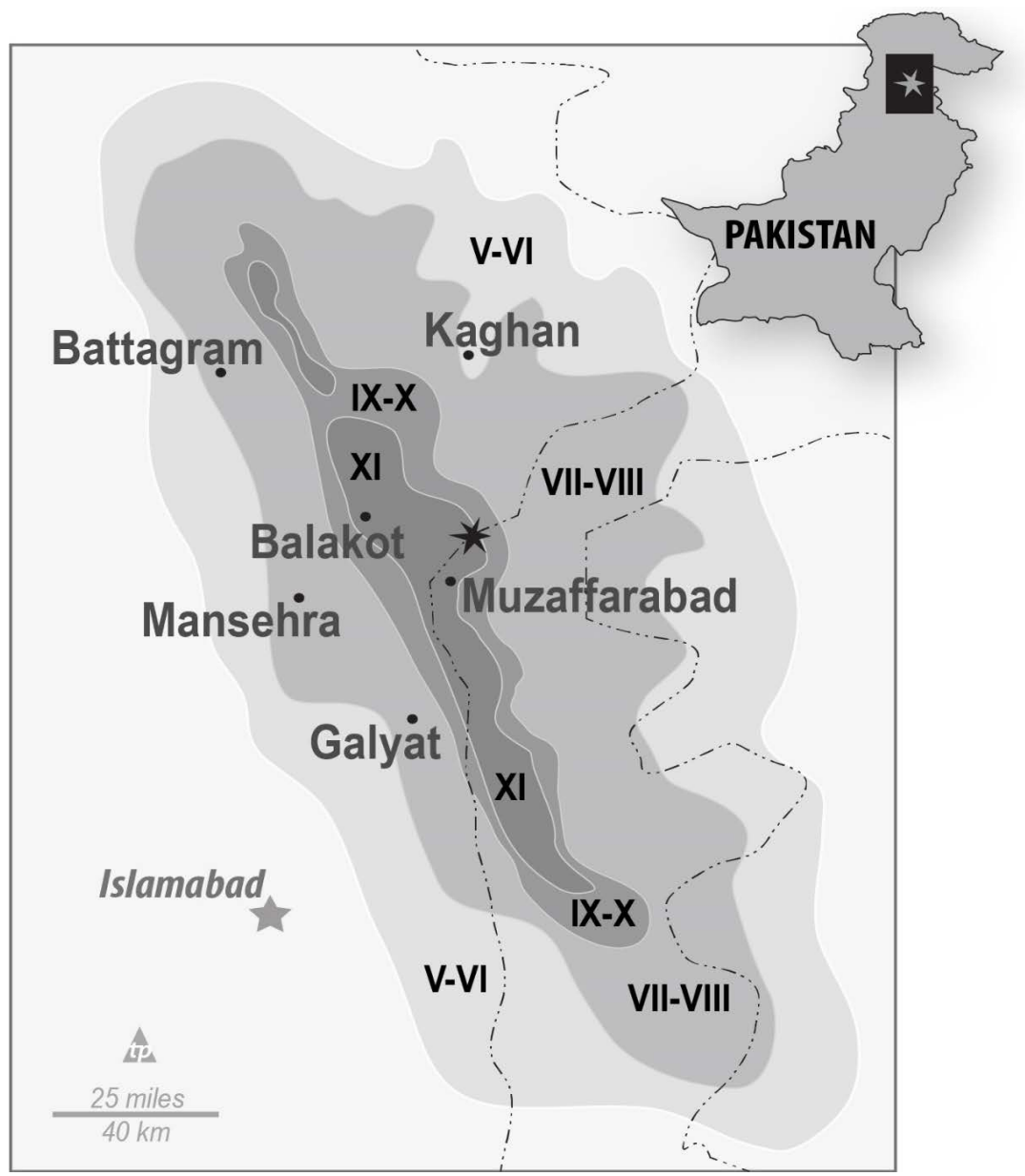

Figure 4. Regional map of the area that sustained the most damage. Shaded areas represent the zones affected by the tremor: MMI or Modified Mercalli Intensity scale (I-XII) represents greatest damage (XI-XII: darkest) to moderate damage (V-VI). (Cartography by the authors, data from USGS [3]). 


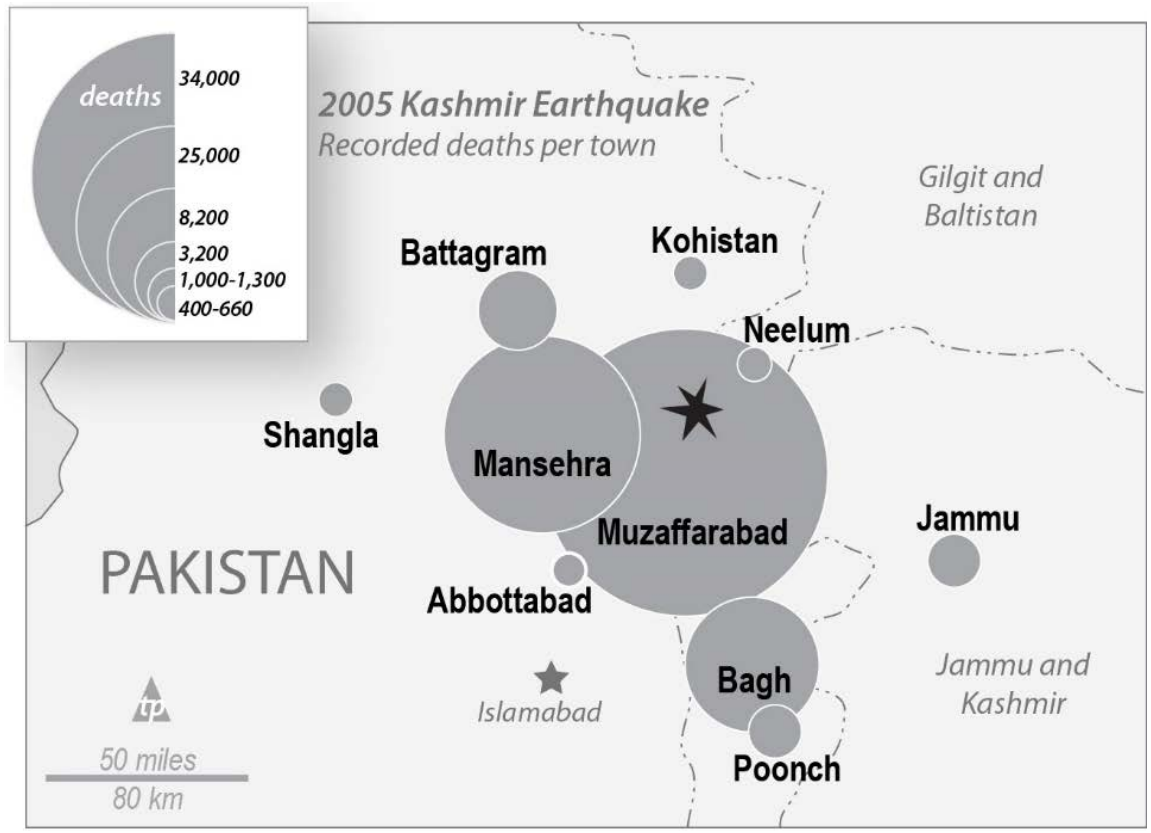

Figure 5. Map representing the recorded deaths caused by the earthquake. Muzaffarabad was most affected with 34,000 deaths. The survey sites were the worst impacted areas in terms of human losses and building collapse (Cartography by the authors, data from Artibees [23]).

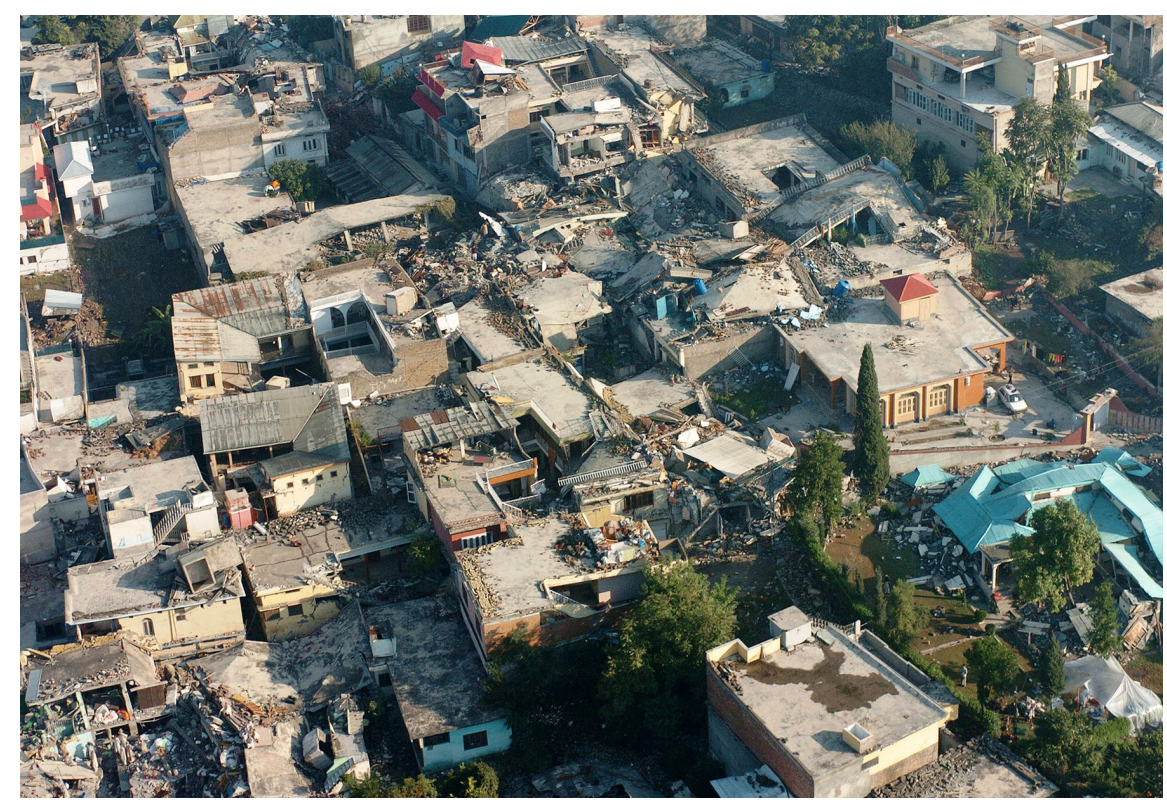

Figure 6. Photograph of the town of Muzaffarabad, near the quake epicenter. Muzaffarabad recorded the highest human loss in a single day and the most extensive damages in its history. The whole city needed to be rebuilt [24].

The first part consisted of five questions that addressed the demographics of the respondents (i.e. age, gender, birthplace, income, education levels). The second part consisted of ten questions that collected data regarding the experiences and perceptions of respondents to earthquakes. For the first four ques- 
tions in the set respondents were provided a number of choices to choose their answers from. The last six questions allowed respondents to answer along a scaled line corresponding to "I fully agree", "agree", "neutral", "disagree", and "fully disagree". Scaled responses enable the researchers to quantify the answers enabling effective descriptive and inferential statistical analyses [22].

A systematic stratified sampling method was used since it was crucial to identify and survey survivors in the five targeted sites, in the three hardest hit districts of KPK. Survey questionnaires were administered to survivors of the earthquake regarding their knowledge, fear, behavior, and concerns of the quake, seismic safety, and preparedness in structured interviews by a trained survey team of Pakistani geography, environmental studies, and geology students from the University of Sindh, Jamshoro who conducted the surveys in the Spring, 2006.

The survey team interviewed 215 respondents who were identified as witnesses, survivors, and/or victims of the October $8^{\text {th }}$ Kashmir Earthquake. Of the 215 interviews, 25 surveys were removed for their incomplete responses; 190 respondent surveys were used in this study. The survey was created for canvassing witnesses in villages where the greatest damages and losses were sustained. The sample size was designed to address the households of these villages and towns impacted the most, based on recorded Modified Mercalli Intensity scale (MMI) values (I-XII) (Figure 4) and actual damages to the region [3].

All surveyed villages were located within 50 miles $(80 \mathrm{~km})$ of the epicenter and, primarily, included the UC Kaghan of Tehsil (sub-district) Balakot of district Mansehra, UC's in Battagram district, and Galyat of Abbottabad district (Figure 4 and Figure 5). 40 - 50 surveys were administered in each village or town. Respondents were asked about their experience with the quake; individuals were approached and asked whether they had experienced the earthquake this was the first question asked to filter each respondent. As expected, some respondents refused to be interviewed due to fear, gender complications, and time availability - not a surprising circumstance in relatively strict Muslim communities such as mountainous Pakistan.

The first four questions of the second part of the questionnaire addressing earthquake experience included:

-Did you experience the recent earthquake on October 5 ?

$\square$ Yes, $\square$ No

- What did you do first during the last earthquake?

$\square$ Did Nothing, $\square$ Ran Away, $\square$ Screamed, $\square$ Sought Cover, $\square$ Prayed

- Will, there ever be another earthquake and if so, when?

$\square$ Yes, $\square$ No: $\square 1$ year, $\square 1$ - 5 year, $\square 6$ - 10 years, $\square 11$ - 20 years

-During an earthquake, it is more dangerous to live in the following.

Countryside, $\square$ Village, $\square$ City, $\square$ Skyscraper

The following six Likert-scaled questions were asked to address perceptions: 
Fully Agree, Somewhat Agree, Neutral, Somewhat Disagree, Fully Disagree

-I believe another earthquake will happen.

- Earthquakes frighten me.

-I believe the buildings in the region are unsafe.

- Earthquakes pose a serious threat to the region.

-I am confident that the local government is prepared for another earthquake.

-I am confident that the national government is prepared for another earthquake.

\section{Research Objectives}

Statistical analysis was employed to ascertain the response of the target population during the earthquake, their understanding of earthquake recurrence, and their level of trust toward the local and national governments about their preparation for another earthquake. Descriptive statistics helped elaborate on the characteristics of the target population who were surveyed for this study. In addition, statistical analyses, both descriptive and inferential, helped in understanding perceptions of seismic risk and behavior. The thrust of this research was to better understand links between behavior, belief, and policy in Muslim communities in the hopes of creating stronger policies that may decrease potential injury, loss, and death in seismically active Pakistan, and across the region.

\section{Demographic Data and Findings}

The male-to-female ratio of respondents was dramatically off-balance; however, this is a common survey result in Muslim communities (male 80\%, female 20\%) unless female sites are specifically targeted (i.e. university campuses, clubs) [22]. However, the age groups represented a more diverse and distributed group. The respondents were all adults $\geq 20$ years in age while the greater share of the respondents (42\%) fell between 31 - 40 years of age. This can be interpreted as a relatively young community; $\sim 79 \%$ of the respondents were younger than 50 years old. The level of attained education reflected in this survey revealed that $35.6 \%$ of the respondents never attended any formal schools (Figure 7).
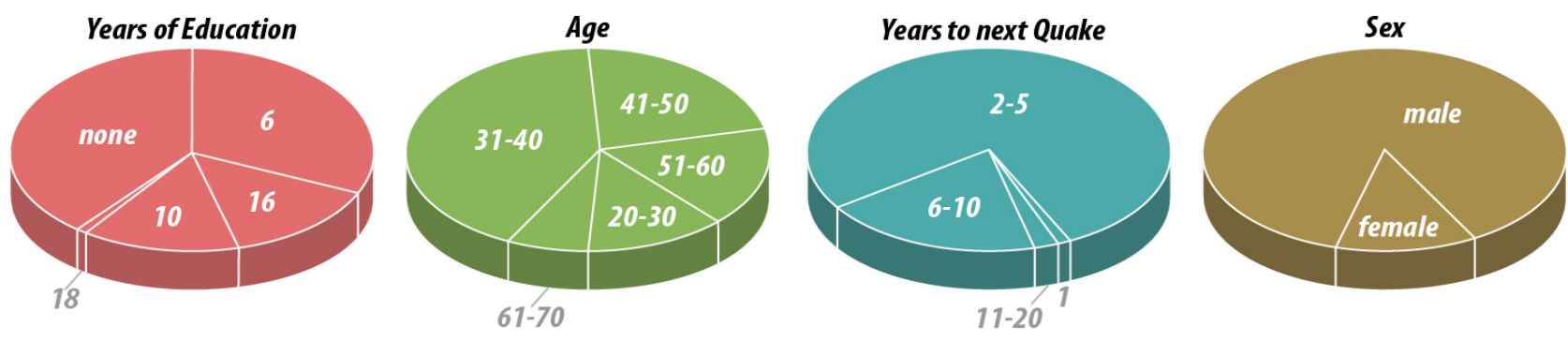

Figure 7. Sectored coin diagrams illustrating the basic demographic information of the survey respondents including their level of education, age, and sex. Also, their response to "when will there be another earthquake?" (n=190). 


\section{Earthquake Experience}

98.9\% of the respondents overwhelmingly said "yes" in response to the question "did you experience an earthquake?". Only three respondents (1\%) gave a negative response. Since nearly every respondent felt the Kashmir Earthquake, the three respondents with negative responses were confidently grouped as outliers. It is probable that these three individuals were not physically present in the area during the earthquake and arrived at the villages later to help with the rehabilitation and reconstruction of their family homes. A large number of residents of north Pakistan who were elsewhere at the time of earthquake, returned home to help with the aftermath of the earthquake. However, there is no way to confirm this since the survey questions do not identify individuals whether they were present or not at the time of the earthquake.

\section{Earthquake Frequency}

$89.2 \%$ of the respondents "fully agreed" with the statement "I believe another earthquake will happen" against $4.2 \%$ who either responded "neutral" or "disagreed". Another important question that informs us of the respondents' perception of risk addresses their understanding of earthquake frequency. Only $6.5 \%$ of the respondents believed there will NOT be an earthquake occurring ever again, while $93.5 \%$ believed there would be another earthquake in the area. However, they differed on the frequency of its occurrence- $71 \%$ of the respondents believed that another major destructive earthquake would strike the region within 2 - 5 years, while another $26.7 \%$ believed an earthquake would strike within 6 10 years (Figure 8). This question serves as an indicator of people's heightened understanding of seismic mechanisms and risk in the northwestern region of Pakistan-relatively higher than related prior studies [21] [22] (Figure 7 and Figure 8).

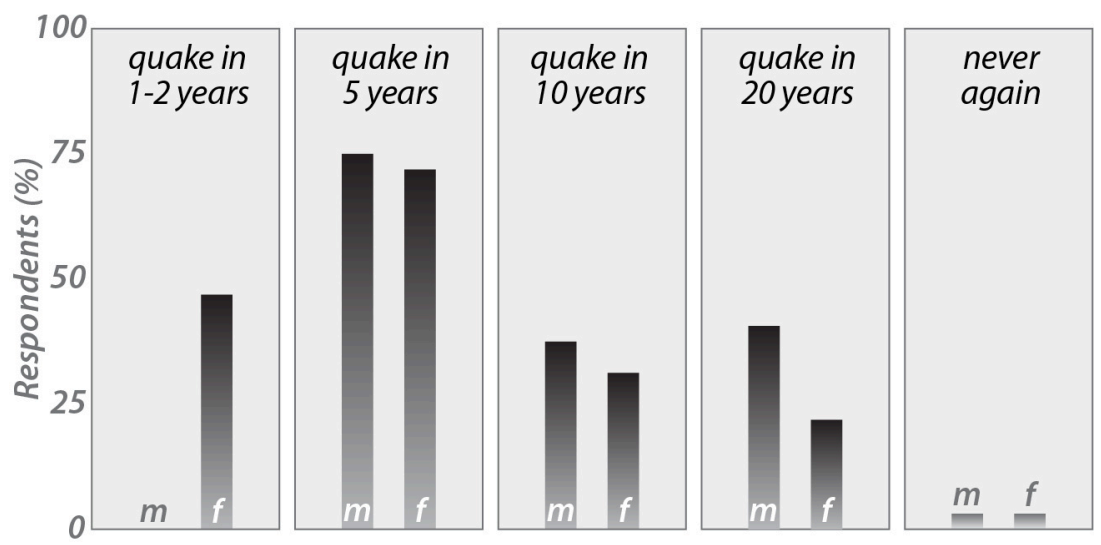

Figure 8. Five bar graphs representing the survey responses regarding the question, "When do you believe the next Earthquake will occur in the region?"-contrasted with sex (male, female). This elaborates relatively heightened perception of risk in females than males especially that nearly all respondents who believed an earthquake would occur in the area in $1-2$ years are all female $(n=190)$. 


\section{Building and Regional Safety}

Surprisingly, $100 \%$ of the respondents stated that they inhabited buildings that they considered unsafe. $93 \%$ of them fully agreed that their home structures were unsafe to inhabit and insecure to quake-related damage and demolition. While another 7\% were "somewhat in agreement" that their buildings were susceptible to earthquake damage and unsafe overall. Similarly, $92.5 \%$ of the respondents were in complete agreement (fully) that "earthquakes posed a serious threat to the Kashmir region".

\section{Confidence in Local and National Governments}

$24 \%$ of the respondents fully agreed that the local government was sufficiently prepared for another earthquake while another $24 \%$ believed that local government was ready for such a situation. $31 \%$ remained neutral, while $21 \%$ expressed complete disagreement with the statement, exhibiting a complete distrust in regional and national earthquake preparedness to any degree (Figure 9). Overall, of the villagers surveyed $48 \%$ stated that the level of regional-national quake preparedness was adequate, while only $21 \%$ believed in no or little governmental seismic preparation of pre- and/or post-event mitigation.

Similarly, a majority of the respondents (26\%) agreed that the national government is fully prepared for another earthquake and $23 \%$ stated that the national government was somewhat prepared. $30 \%$ stated that they remained neutral, and $21 \%$ disagreed with the current state of earthquake preparedness; hence $49 \%$ believed in apparent preparedness, and $21 \%$ disagreed with the assessment.

\section{Perception of Danger}

The fundamental question that addressed preparedness, consequences and/or danger was related to the actions taken by respondents as the earthquake struck. Post-event behavior is key to comprehending personal and community dread and can help assess a community's perceived state of preparedness and response [19]. 30\% of the respondents did nothing while the majority (cumulatively 70\%) responded to the earthquake by running away, screaming, or praying (Figure 10). Nearly a quarter of the surveyed population took no action to save themselves from the collapsing buildings and loose objects in their immediate surroundings. This is surprising to note especially in a seismically active region. However, this in-action in earthquakes, in Muslim communities, have been associated with their interpretation of earthquakes as an act of divine retribution [22] [25], and divine test [26]. Although praying can be attributed to inaction, it has been identified as an integral part of general risk perception facilitated by relatively fatalistic postures displayed in communal Islamic perceptions of earthquakes only, and not all-natural hazards [21] [27] [28]. This has been attributed to the importance of the Quranic chapter (Chapter 99 Az-Zalzalah, or "the Earthquake") that specifically associates divine retaliation with earthquakes [22] [28]. 

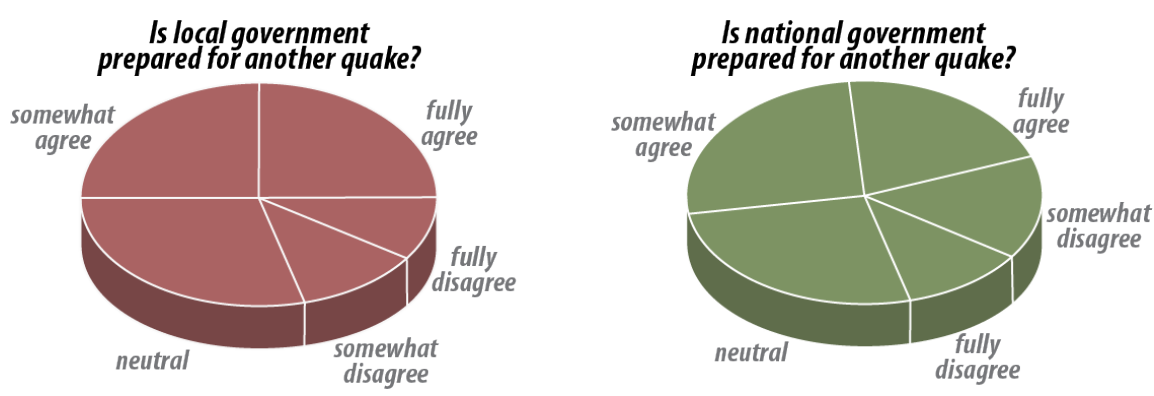

Figure 9. Sectored coin diagrams illustrating respondents' perception of trust in government regarding their preparation for another probable earthquake in the future $(n=190)$.

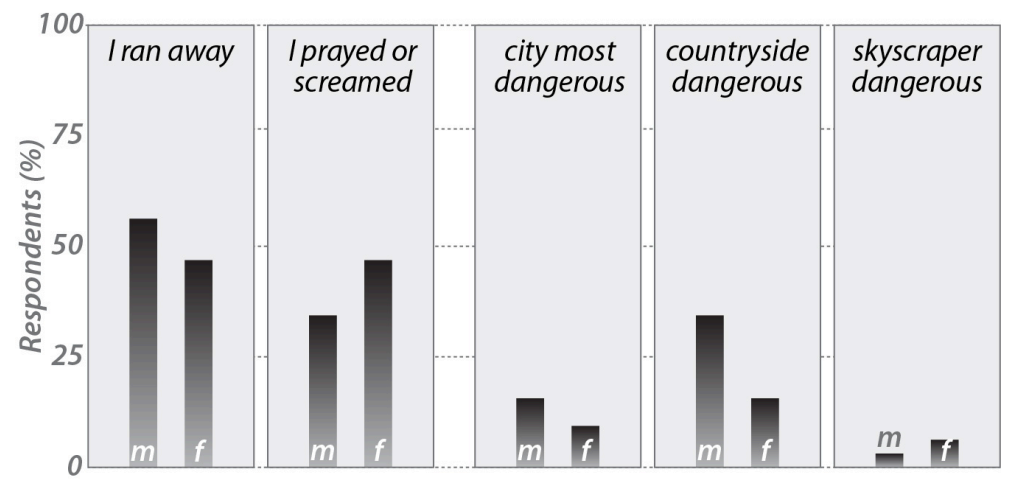

Figure 10. Five bar graphs representing the survey responses regarding two questions, "What did you do once the quake struck?" (left), and "where is it most dangerous to live during an earthquake?" (right) $(\mathrm{n}=190)$.

The nature and proportion of responses varied across age groups and education levels. When correlated against education attained, the type of action or inaction adopted by the respondents confirmed findings by researchers in prior seismic risk perception studies [25]. Their actions were found to be strongly correlated to their education with a correlation of determination of $\mathrm{r}^{2}=0.403$. When the behavior was separated into action (running away, screaming, praying) vs. inaction (did nothing), the $\mathrm{r}^{2}$ revealed a 0.98 correlation indicating that inaction was rare or statistically non-existent. Hence, the higher the level of education is, the stronger the tendency to react actively to the tremor.

An overwhelming majority (80\%) of the respondents believed that living in villages was more dangerous in the event of an earthquake (Figure 10). This can be due to the fact that the living environment influences one's risk perception [19] and the observed destruction of the target sites would have enhanced their responses.

The correlation of determination for the variable ran away was strongest at $\mathrm{r}^{2}$ $=0.97$ for the number of people who took action in response to the earthquake (Figure 10) indicating that those with higher education were more apt to run away (escape) in response to the quake. Irrespective of the level of education or any other explanatory variable, a strong correlation was noted between all demographic categories and ran away. This could be interpreted as the first act one 
would naturally perform - an instinctive behavior among human (and creatures). It may be assumed that since the tremor was strong, people were frightened, and they reacted by escaping. However, none $(0 \%)$ of the respondents sought cover (Figure 11), an act interpreted as a lack of knowledge of conventional earthquake preparedness measures whereby one would drop, cover, and hold.

\section{Discussion and Conclusion}

Risk perception in seismically active regions like Kashmir, is fundamentally important to disaster managers, research scholars, and emergency institutions and services. Perception is formed and defined by one's knowledge and experience gained over time, and the context of the situation [22]. In the paradigm of disaster management, the area of preparedness has been studied extensively through psychometric [29] [30] and/or social-environmental approaches [31]. In risk perception research, education, age, gender, and income levels are found to correlate strongly with various types and degrees of risk perception-the freshness of an event is found to spike risk perceptions as well [19].

In this study, education was examined in the context of increased awareness and actions taken during the earthquake. The negative correlations between education and no-action, and the strong positive correlations between education and action provided evidence of the crucial role of education in increasing perceptions leading to action during an earthquake, whether formal education or informative discussions through conventional media outlets (e.g. radio, print, internet, tv). Similar findings regarding the importance and influence of media-sourced information have been previously identified and emphasized [21] [28].

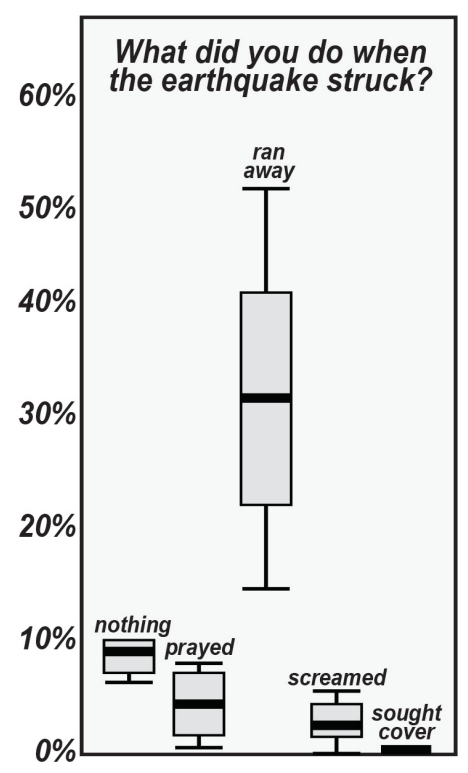

Figure 11. Whisker bar diagrams representing the survey responses to the question, "What did you do when the earthquake struck?" $(\mathrm{n}=190)$. 
Moreover, the level of trust in the government's response and preparedness was also tested. Half of the respondents expressed some degree of trust in their local and national government regarding their capacity and preparedness for another earthquake event, a rare community opinion when compared to prior research [25].

Of interesting note is that none of the residents sought cover during the earthquake. This might be disputed as to whether it was the right thing to do in this specific event and context. However, a lack of information about "seeking cover" as an appropriate action especially while indoors demonstrates a general lack of their awareness. In general earthquake education, drop, cover, and hold are prescribed and are considered recommended action during an earthquake to increase safety from falling objects.

This analysis presents an individual and community perception that represents a relatively higher perception of seismic risk than many communities, although they appear as vastly unprepared to take appropriate actions. This more acute perception might be biased because of the short lag-time between the event and survey-a rare circumstance in perception studies and the power of this research project [19]. It is a rare occasion that individuals can be surveyed with six months of such a strong and dreadful event.

Overall, this research revealed both conventional findings and unexpected (and rare) results. The often-cited fatalistic influences of Islam on its communities were supported in these findings in that Muslim communities may have a lesser tendency to prepare for earthquake due to the singular link between divine retribution and earthquakes in the Qur'an [22]. However, surprising results included the strong relationship between education and defensive actions during and after the event.

The point of perception studies in natural hazards and risk research is paramount in that as our technologies increase our understanding of seismic mechanisms and potential seismic forecasting, without further understanding of local, regional, and national perceptions of risk and influence, policy-makers will not be able to effectively decrease injury, loss, and death from natural disasters-the ultimate goal of natural hazard and risk research today.

\section{Conflicts of Interest}

The authors declare no conflicts of interest regarding the publication of this paper.

\section{References}

[1] U.S. Geologic Survey (2005) Kashmir Earthquake. https://earthquake.usgs.gov/earthquakes/eventpage/usp000e12e/technical

[2] Özerdem, A. (2006) The Mountain Tsunami: Afterthoughts on the Kashmir Earthquake. Third World Quarterly, 27, 397-419. https://doi.org/10.1080/01436590600587846

[3] U.S. Geological Survey (2005) Event Page: Magnitude 7.6-Pakistan, Reston. https://earthquake.usgs.gov/earthquakes/eventpage/usp000e12e/executive 
[4] Bendick, R., Bilham, R., Khan, M. and Khan, S. (2007) Slip on an Active Wedge Thrust from Geodetic Observations of the 8 October 2005 Kashmir Earthquake. Geology, 35, 267. https://doi.org/10.1130/G23158A.1

[5] Bothara, J.K. and Hiçyılmaz, K.M.O. (2008) General Observations of Building Behaviour during the 8th October 2005 Pakistan Earthquake. Bulletin of the New Zealand Society for Earthquake Engineering, 41, 209-233. https://doi.org/10.5459/bnzsee.41.4.209-233

[6] Earthquake Reconstruction and Rehabilitation Authority (2006) Strategy Document Rural Housing Construction, Building Back Better: Rural Housing Reconstruction Strategy of Earthquake Hit Districts in NWFP and AJK. Earthquake Reconstruction and Rehabilitation Authority, Islamabad.

[7] Halvorson, S.J. and Parker-Hamilton, J. (2010) In the Aftermath of the Qa'yamat: the Kashmir Earthquake Disaster in Northern Pakistan. Disasters, 34, 184-204. https://doi.org/10.1111/j.1467-7717.2009.01124.x

[8] Bindra, S., Naqvi, S.M. and Raedler, J. (2005) Pakistan Puts Quake Toll at 18,000. CNN World Edition.

[9] Ismail, N. and Khattak, N. (2016) Building Typologies Prevalent in Northern Pakistan and Their Performance during the 2015 Hindu Kush Earthquake. Earthquake Spectra, 32, 2473-2493. https://doi.org/10.1193/012116EQS022M

[10] U.S. Geological Survey (2013) Event Page: M7.7-61km NNE of Awaran, Pakistan, Reston, VA.

http://earthquake.usgs.gov/earthquakes/eventpage/usb000jyiv\#general summary.

[11] Hussain, A., Yeats, R. and MonaLisa (2008) Geological Setting of the 8 October 2005 Kashmir Earthquake. Journal of Seismology, 13, 315-325.

https://doi.org/10.1007/s10950-008-9101-7

[12] Yeats, R.S., Kausar, A.B., and Nakata, T. (2006) Conferees Examine Deadly 2005 Kashmir Earthquake. Eos, Transactions American Geophysical Union, 87, 115. https://doi.org/10.1029/2006EO110006

[13] Kumahara, Y. and Nakata, T. (2006) Active Faults in the Epicentral Area of the 2005 Pakistan Earthquake. Hiroshima University Research Center for Regional Geography Special Publication 41, Hiroshima University Research Center for Regional Geography, Hiroshima.

[14] Kaneda, H., Nakata, T., Tsutsumi, H., Kondo, H., Sugito, N., Awata, Y., Akhtar, S., Majid, A., Khattak, W., Awan, A., Yeats, R., Hussain, A., Ashraf, M., Wesnousky, S. and Kausar, A. (2008) Surface Rupture of the 2005 Kashmir, Pakistan, Earthquake and Its Active Tectonic Implications. Bulletin of the Seismological Society of America, 98, 521-557. https://doi.org/10.1785/0120070073

[15] 08 October 2005 Earthquake-The Harrowing Memories That Still Vex. Dunya News. (2020) Retrieved 7 November 2020.

https://dunyanews.tv/en/Pakistan/460912-08-October-2005-

[16] Akhtar, A.S. (2006) Making of a Disaster. Economic and Political Weekly, 41, 479-480.

[17] Avouac, J.P., Ayoub, F., Leprince, S., Konca, O. and Helmberger, D.V. (2005) The 2005, Mw 7.6 Kashmir Earthquake: Sub-Pixel Correlation of ASTER Images and Seismic Waveforms Analysis. Earth \& Planetary Science Letters, 249, 514-528. https://doi.org/10.1016/j.epsl.2006.06.025

[18] Earth Observatory of Singapore (2018) Before and after Imagery of Makhri Landslide, Pakistan.

https://earthobservatory.sg/blog/looking-back-2005-kashmir-earthquake 
[19] Burton, I., Kates, R. and White, G. (1993) The Environment as Hazard. The Guilford Press, London, $290 \mathrm{p}$.

[20] Haque, C.E. and Blair, D. (1992) Vulnerability to Tropical Cyclones: Evidence from the April 1991 Cyclone in Coastal Bangladesh. Disasters, 163, 217-29.

https://doi.org/10.1111/j.1467-7717.1992.tb00400.x

[21] Hutton, D., and Haque, E. (2004) Human Vulnerability, Dislocation and Resettlement: Adaptation Processes of River-Bank Erosion-Induced Displacees in Bangladesh. Disasters, 28, 41-62. https://doi.org/10.1111/j.0361-3666.2004.00242.x

[22] Paradise, T.R. (2005) Perception of Earthquake Risk in Agadir, Morocco: A case Study from a Muslim Community. Global Environmental Change Part B: Environmental Hazards, 6, 167-180. https://doi.org/10.1016/j.hazards.2006.06.002

[23] Artibees (2018) Earthquake 2005 in Pakistan. http://artibees.com/2018/10/08/earthquake-2005-in-pakistan/

[24] 2005 Kashmir Earthquake-Alchetron, the Free Social Encyclopedia. Alchetron.com. (2020). Retrieved 7 November 2020.

https://alchetron.com/2005-Kashmir-earthquake

[25] Ainuddin, S., Routray, J.K. and Ainuddin, S. (2014) People's Risk Perception in Earthquake-Prone Quetta City of Baluchistan. International Journal of Disaster Risk Reduction, 7, 165-175. https://doi.org/10.1016/j.ijdrr.2013.10.006

[26] Farhang, M. (2004) Earthquake: Misfortune, Injustice, or the Will of God? From Bam to Lisbon. Dissent, 51, 65-72.

https://www.dissentmagazine.org/article/earthquake-misfortune-injustice-or-the-wi ll-of-god

[27] Alshehri, S., Rezgui, Y. and Li, H. (2013) Public Perception of the Risk of Disasters in a Developing Economy: The Case of Saudi Arabia. Natural Hazards, 65, 1813-1830. https://doi.org/10.1007/s11069-012-0445-5

[28] Paradise, T.R. (2008) Earthquakes and Islam: Case Studies from Morocco. Journal of Islamic Law \& Culture, 10, 216-233. https://doi.org/10.1080/15288170802285447

[29] Slovic, P. (2009) The Perception of Risk. Earthscan, London.

[30] Slovic, P. (1987) Perception of Risk. Science, 236, 280-285. https://doi.org/10.1126/science.3563507

[31] Tobin, G. and Montz, B. (1997) Natural Hazards. Guilford Press, New York. 